\title{
Rolapitant Hydrochloride
}

National Cancer Institute

\section{Source}

National Cancer Institute. Rolapitant Hydrochloride. NCI Thesaurus. Code C97955.

The hydrochloride salt form of rolapitant, an orally bioavailable, centrally-acting, selective, neurokinin 1 receptor (NK1-receptor) antagonist with potential antiemetic activity. Upon oral administration, rolapitant competitively binds to and blocks the activity of the NK1receptor in the central nervous system, thereby inhibiting the binding of the endogenous ligand, substance P (SP). This may prevent both SP-induced emesis and chemotherapyinduced nausea and vomiting (CINV). The interaction of SP with the NK1-receptor plays a key role in the induction of nausea and vomiting caused by emetogenic cancer chemotherapy. Compared to other NK1-receptor antagonists, rolapitant has both a more rapid onset of action and a much longer half-life. 